\title{
Copyright and Live Streaming of Sports Broadcasting
}

\author{
Dr Kanchana Kariyawasam* \& Matthew Tsai*
}

\begin{abstract}
:
The inception of live streaming technology has rapidly changed the way in which sporting events are transmitted. The unauthorised retransmission of live sports telecasts over the Internet has become one of the main concerns in sports media, where broadcasters have lost billions of dollars' worth of sports broadcasting contracts and sponsorship deals. The scale of this problem has caused serious harm, both to sports rights-holders and to broadcasters. Legislative reforms are required in order to balance the public's ever-increasing desire for convenient ways to view digital materials against the legal rights of the owners of the material, while also aiming to maintain a forward-looking perspective in an attempt to foresee potential technological advancements that may pose considerable challenges to the traditional copyright law. This article analyses how the concept of live streaming of live sports has changed the legal landscape.
\end{abstract}

\section{Introduction}

The digital age has long been recognised as the forefront of progress. Indeed, the rapid evolution of digital communication has provided significant utilitarian benefits to the community, not just in terms of access, but in enhancing the long-held freedom of expression. They have opened up new horizons for communication, allowing people to connect to a global network. One notable impact of digital technology has been on the way sports are watched. Advancements in technology have enabled consumers to shift away from traditional methods of viewing sports content (via specific sports channels on television) ${ }^{1}$ to digital technologies involving internet streaming through mobile phones, tablets and other devices that can connect to the Internet. These advances have provided greater flexibility and ease-of-access for sports fans to engage with content. ${ }^{2}$

At the same time, it has also presented a number of challenges on the protection of intellectual property, particularly in the field of copyright. It has required legislation to be continually updated in order to ensure that a reasonable and commercially viable balance is maintained between the rights of copyright owners and users of works in which copyright subsists. This is has been exemplified by the effect of live streaming on the way sport is delivered and watched. Live streaming has been heralded as a new era in sports broadcasting, ${ }^{3}$ but it has also provided greater opportunities for individuals to contravene the law and obtain unauthorised broadcasts of live sports. Not surprisingly, the illegal streaming of live sports broadcasts has posed considerable challenges to the traditional copyright landscape.

\footnotetext{
* PhD (Griffith University), LL.M (Advanced) (UQ) \& LL.B (Hons) (Colombo), Senior Lecturer in Business Law, Business School, Griffith University, Australia.

* BA / LLB (Hons I) (The University of Queensland), Graduate Consultant at Ernst \& Young, Sydney.

${ }^{1}$ Paul Turner, 'The Impact of Technology on the Supply of Sport Broadcasting' (2007) 7(4) European Sport Management

Quarterly 337, 337-8.

${ }^{2}$ Brett Hutchins., 'Sport on the Move: The Unfolding Impact of Mobile Communications on the Media Sport Content

Economy’ (2014) 38(6) Journal of Sport and Social Issues 509, 510-511.

3 Broadcast Australia., 'The (r)evolution of sports broadcasting' (2007).
} 
Unfortunately, the degree to which copyright law doctrines apply in these circumstances remains unclear.

Copyright infringements of broadcasted sports content are frequent and occur on an international scale due to the massive popularity of sports content and the online nature of content-sharing. ${ }^{4}$ The profits that would ordinarily accrue from individuals engaging with content legally (by paying for the right to watch their broadcasts) are inevitably taken away by live streaming. On this basis, live streaming effectively lands a double-strike to the sports broadcasting industry as it siphons off potential customers and profits, while still (unlawfully) using sport broadcasters' content. Indexing websites, for instance, provide a central location where users can find links to sporting events without actually hosting the content. ${ }^{5}$

The commercial sports industry has taken a cautious approach to new live streaming technologies out of fear that unauthorised rebroadcasting of sporting events could impair the marketability and profitability of licensed sports broadcasts. ${ }^{6}$ Broadcasting rights are perhaps the most important asset to amateur and professional sports leagues and organisations. ${ }^{7}$ In fact, the exclusive sale of broadcasting rights to sporting events is the largest source of revenue for many sporting leagues and is essential for their success. ${ }^{8}$ The massive royalties that broadcasters earn from selling their exclusive footage to other media outlets enables them to invest in the costly organisational and technical undertakings involved in broadcasting sports events to millions of fans all over the world. ${ }^{9}$ Broadcasters therefore consider exclusivity to guarantee the value of a given telecast, ${ }^{10}$ and are continually seeking to ensure that returns from their significant financial investment are not unjustly diverted to third parties.

This article examines the development of live streaming of sports broadcasts, its impact on the legal landscape and an analysis of some uncertainties in copyright law in Australia, and the need for legal reform.

\section{Sports broadcasting - From humble beginnings to big business}

Australia's first world champion in any sport was Edward 'Ned' Trickett, who in 1876 won the world sculling championship on London's Thames River. ${ }^{11}$ The news was transmitted by mail steamer to Port Adelaide and then relayed by telegraph

\footnotetext{
${ }^{4}$ The international nature of intellectual property is also reflected in international agreements and conventions that attempt to address intellectual property protection across jurisdictions like the Berne Convention for the Protection of Literary and Artistic Works (1886), World Intellectual Property Organisation (WIPO) (1974) and the Agreement on Trade Related Aspects of Intellectual Property (TRIPS) (1994); See Mark Davidson (et al)., Australian Intellectual Property (Cambridge University Press, $2^{\text {nd }}$ ed, 2012).

${ }^{5}$ Stephanie N. Horner., Comment, DMCA: Professional Sports Leagues’ Answer To Protecting Their Broadcasting Rights Against Illegal Streaming, (2014), 24 Marquette Sports Law Review 435, 438 quoted in Adam Ainslie., 'The Burden of Protecting Live Sports Telecasts: The Real Time Problem of Live Streaming and AppBased Technology’ (2015) at $<$ http://ssrn.com/abstract=2729641 > (last accessed 17 October 2016).

${ }^{6}$ Marc Edelman., 'From Meerkat to Periscope: Does Intellectual Property Law Prohibit the Live Streaming of Commercial Sporting Events’ (2016) 39 (4) Columbia Journal of Law \& the Arts 469, 470-471.

${ }^{7}$ Michael J Mellis., 'Internet Piracy of Live Sports Telecasts’ (2008) 18 (2) Marquette Sports Law Review $259,259$.

${ }^{8}$ Allison Lincoln., The Global Politics of Sport: the Role of Global Institutions in Sport (Routledge (April 13, 2005) $259,284$.

${ }^{9}$ Broadcasting \& Media Rights in Sport

at <http://www.wipo.int/ip-sport/en/broadcasting.html > (last accessed 14 October 2016).

${ }^{10}$ Coopers \& Lybrand., 'The Impact of European Union Activities on Sport' (1995) 17 Loy. L.A. Int'l \& Comp. L. Rev. 245 quoted in Mark Meltz., 'Hand It Over: Eurovision, Exclusive EU Sports Broadcasting Rights, and the Article 85(3) Exemption' (1999) 23 (1) Boston College International and Comparative Law Review 105, 106.

${ }^{11}$ John Nauright., Charles Parrish., Sports Around the World: History, Culture, and Practice (2012, USA) at 429.
} 
across the nation, finally reaching Sydney three weeks later. ${ }^{12}$ As Australia prospered and developed economically, technology became more freely available, which allowed a larger cross-section of the Australian community to view and access information on sporting events. The first newspaper devoted entirely to sporting news, The Referee, was published in Sydney in $1886 .{ }^{13}$ Since then, the sports broadcasting industry has experienced significant growth as a result of advancements in the technology and media industries. The development of modern sports broadcasting has provided viewers with a virtual front-row seat at a number of the world's premier sporting events. ${ }^{14}$

One example of the changing face of Australian sport has been the expansion of Australia's most famous horse race, the Melbourne Cup, over the last century. When the event was first held in 1861, it attracted 4000 viewers. By 2003, the 'race that stops the nation' had been broadcast to a potential global audience of 700 million people. ${ }^{15}$ From its humble beginnings, where a single camera was used to capture the action, sports telecasting has developed into a multi-billion-dollar-a-year industry, where broadcast rights and sponsorships deals are often construed as more fundamental than on-field umpiring decisions and sportsmanship. ${ }^{16}$ However, the rapid development of the industry was arguably attributed to the Olympics games. Prior to the 1980s, the broadcasting of the Olympics was typically overseen by the host country's national broadcaster. ${ }^{17}$ This presented a number of shortcomings with the quality and diversity of international television coverage as host countries primarily focused on their own athletes. Naturally, this minimised interest from both viewers and sponsors from other countries, ${ }^{18}$ but this was subsequently rectified by the International Olympic Committee (IOC) who took a more active role in coordinating broadcast rights and providing a more balanced coverage. ${ }^{19}$ In 2001, the IOC established the Olympic Broadcasting Services (OBS) to serve as the permanent host broadcaster for the Olympic Games, eliminating the need to continually re-establish a local broadcaster each time the Games were held. ${ }^{20}$ This coverage would then be supplied to Rights Holding Broadcasters (RHBs) who could supplement the feeds with their own country-specific coverage. The fact that RHBs could bid for geographical coverage rights for the Olympic Games resulted in unprecedented levels of sponsorship and advertising revenue. ${ }^{21}$ The fresh influx of capital for sports broadcasters led to a technological revolution with respect to the manner in which sports content was delivered.

Sport is an important part of Australian culture. Australia is one of the few countries in the world where sport forms such a persuasive and influential aspect of culture and society where it has become instrumental in establishing a collective sense of

\footnotetext{
${ }^{12}$ R Cashman., Sport in the National Imagination, (Walla Walla Press Sydney 2002) 208.

${ }^{13}$ Sport and the Media (2013) Australian Government <http://australia.gov.au/about-australia/australian-story/sport-and-themedia> (last accessed 2 December 2016).

${ }^{14}$ The (r)evolution of sports broadcasting (2007).

${ }^{15}$ Sport and the Media (2013) Australian Government < http://australia.gov.au/about-australia/australian-story/sport-and-themedia> (last accessed 12 October 2016).

${ }^{16}$ Peter Kepreotes., 'The revolution of sports broadcasting' (2007) Broadcast Australia Feature Story 1, 2.

${ }^{17}$ Boradcast Australia, 'The (r)evolution of sports broadcasting' (2007).

${ }^{18}$ Peter Kepreotes., ‘The revolution of sports broadcasting’ (2007) Broadcast Australia Feature Story 1, 2.

${ }^{19}$ Boradcast Australia., 'The (r)evolution of sports broadcasting' (2007).

${ }^{20}$ International Olympic Committee, Olympic Broadcasting (2013) at <http://www.olympic.org/olympic-broadcasting > (last accessed 12 October 2016)

${ }^{21}$ Peter Kepreotes., 'The revolution of sports broadcasting' (2007) Broadcast Australia Feature Story 1, 2.
} 
identity, pride and self of sense for Australians. ${ }^{22}$ Australians like watching sport on television and there is a long history of television coverage of sports in Australia. In 2014 , four of the top five rating television programs were sporting events. ${ }^{23}$ It is estimated that 88 per cent of respondents believe sporting events should be available to all Australians for free. ${ }^{24}$

In general, one of the reasons for the growing popularity of sport on television was its immediacy. ${ }^{25}$ The direct transmission of sporting events into the home, which was 'both an essential characteristic and an aesthetic value of the new medium' ${ }^{26}$ created a sense of immediacy that gradually undermined the value of newsreels. ${ }^{27}$ The attraction of television was also the fact that it was distinguished from radio commentary, which was increasingly seen as a form of press reporting that provided a 'second-hand coded narrative or description of play and unlike television did not convey the sports event in its entirety'. ${ }^{28}$ However, sporting codes originally viewed the emergence of television as a household commodity with scepticism, fearing that their ticket sales revenue could drop from viewers electing not to attend games in person. ${ }^{29}$ Nonetheless, subsequent decades showed that television broadcasts actually created massive revenue increases for these sporting codes because of advertising revenue. ${ }^{30}$ The increase in the number of broadcasters and the rise of commercial broadcasting explain the evolution of the sale of sports broadcasting rights over the past 20 years. ${ }^{31}$ Originally, 'where public television was dominant, public networks carried some sports events and, as monopolists, paid relatively small fees for these rights' ${ }^{32}$ With the development of pay television, recently upgraded free-to-air channels, and various easily accessible online services, it is now possible for members of the public to view a range of sports from the comfort of their own living rooms.

\section{Live streaming of sports}

Streaming involves 'any audio or video content delivered over a network based on Internet protocols' and is different from the traditional process downloading. ${ }^{33} \mathrm{~A}$ download requires a computer to copy an entire file onto a hard disk before it can be accessed. Streaming, however, does not require content to be saved as users view or

\footnotetext{
${ }^{22}$ Brett Hutchins, David Rowe., Sport Beyond Television: The Internet, Digital Media and the Rise of Networked Media Sport (Routledge, 2012)

${ }^{23}$ TV Trends 2014, quoted in Sports Broadcasting at

<https://www.clearinghouseforsport.gov.au/knowledge_base/organised_sport/sports_and_sports_organisations/sports_media_b roadcasting_and_communication> (last accessed 12 December 2016).

${ }^{24}$ Free TV Australia, Media Release 1 February 2016.

${ }^{25}$ Brad Sherman (et al)., Copyright and the Challenge of the New (2012, Kluwer Law International, The Netherlands) at 221.

${ }^{26}$ Richard Haynes., 'A Pageant of Sound and Vision: Football's Relationship with Television, 1936-60', The International Journal of the History of Sport 15(1) (1998): 211, 211, quoted in Brad Sherman., 'Copyright and the Challenge of the New (2012, Kluwer Law International, The Netherlands) at 222.

${ }^{27}$ Brad Sherman (et al.)., Copyright and the Challenge of the New (2012, Kluwer Law International, The Netherlands) at 221.

${ }^{28}$ Ibid 216. See also J. Caughie, 'Before the Golden Age: Early Television Drama' in Popular Television in Britain: Studies in

Cultural History, ed. J. Corner (London: BFI, 1991), 23, quoted in Brad Sherman (et al.)., Copyright and the Challenge of the New (2012, Kluwer Law International, The Netherlands) at 221.

${ }^{29}$ Darryl Wilson., 'The Cable TV-Sports Broadcasting Nexus' (1986) 8(1) Communications and the Law 43, 44.

${ }^{30}$ Darryl Wilson., 'The Cable TV-Sports Broadcasting Nexus' (1986) 8(1) Communications and the Law 43, 44.

${ }^{31}$ Roger G. Noll., 'Broadcasting and Team Sports' (2007) SIEPR Discussion paper at 6.

${ }^{32}$ Roger G. Noll., 'Broadcasting and Team Sports' (2007) SIEPR Discussion paper at 6.

${ }^{33}$ David Austerberry., Technology of Video and Audio Streaming (Focal Press [Imprint], 2002) at 15; Borghi M., 'Chasing copyright infringement in the streaming landscape’ (2011) 43 (3) IIC International Review of Intellectual Property and Competition Law 316-343.
} 
listen to the digital work in real time. ${ }^{34} \mathrm{~A}$ couple of seconds of data is buffered at a time and subsequently deleted once played. ${ }^{35}$

Individuals can contribute to and access unauthorised online streaming through a number of ways. One method of live streaming is through a peer-to-peer (P2P) network, where all computers are linked together and can communicate with each other independently without the presence of a third-party server. P2P technology is a popular form of online consumption of sports broadcasts and is characterised by one person sharing content with another person online without any personal interaction. ${ }^{36}$ This technology is used to power platforms like Spotify (a Swedish music, podcast and video streaming service) as well as infamous torrent sites like Pirate Bay. This trend was first seen in the music industry through music file sharing and has graduated to other forms of entertainment, such as movies and television shows. This process of spreading information has been linked with the rise of globalisation and the increasing interconnectedness between people, governments, corporations and organisations that transcends national boundaries due to modern technologies. Some P2P networks (like Spotify) are legitimate, however most P2P networks are wholly unauthorised as they involve viewers sharing content with other viewers in a nonprivate or domestic situation. ${ }^{37} \mathrm{P} 2 \mathrm{P}$ technology is perhaps the most serious threat to the sustainability and the economic longevity of sports broadcasting. ${ }^{38}$

Another method of live streaming involves 'unicast streaming', where material is saved on a server and made available to users on a website. ${ }^{39}$ Since it requires more bandwidth and computer processing than P2P technology, unicast streaming often requires a paid subscription fee. ${ }^{40}$ The majority of unauthorised live streaming of sports is conducted through this technology. ${ }^{41}$

Perhaps the most ingenious (and most elaborate) method of livestreaming involves the use of set top boxes, which are normally required to access subscription only content like Foxtel. When an individual pays for a regular subscription, they receive a set top box to view the content. Pirates pay for a regular subscription, but use the set top box to send digital feeds to other servers where they can on-sell the content to a broader audience at a cheaper rate. ${ }^{42}$ This was the case with realsportsstreams.com, which was illegally supplying Sky and Foxtel broadcasts. ${ }^{43}$ Viewers who pay for this cheaper service have two options to access the content: they can either use a free software media player to access the content online, or

\footnotetext{
${ }^{34}$ Borghi M., 'Chasing copyright infringement in the streaming landscape' (2011) 43 (3) IIC International Review of Intellectual Property and Competition Law 316-343; Adam Ainslie, above n 5.

${ }^{35}$ Adam Ainslie., above n 5.

${ }^{36}$ For a detailed account on the history of P2P technology see Chia-heng Seetoo., 'Can Peer-To-Peer Internet Broadcast Technology Give Fans Another Chance? Peer-To-Peer Streaming Technology and Its Impact’ (2007) Law, Technology \& Policy 369-394.

${ }^{37}$ Thus fails to meet exceptions allowed in s111 of the Copyright Act.

${ }^{38}$ Chia-heng Seetoo, 'Can Peer-To-Peer Internet Broadcast Technology Give Fans Another Chance? Peer-To-Peer Streaming Technology and Its Impact’ (2007) 2007 Law, Technology \& Policy 369, 394.

${ }^{39}$ Rafael Ferraz Vazquez., 'Sport and broadcasting rights: adding value', WIPO Magazine (2013).

${ }^{40}$ Seagull Haiyan Song., 'How Should China Respond to the Online Piracy of Live Sports Telecasts? A Comparative Study of Chinese Copyright Legislation to US and European Legislation’ (2011) 9 University of Denver Sports and Entertainment Law Journal 3, 21.

${ }^{41}$ Michael J. Mellis., 'Internet Piracy of Live Sports Telecasts’ (2008) 18 Marq. Sports L. Rev 259, 260.

42 Jeff Stone., 'Forget The Pirate Bay: Use These Illegal Sports Streaming Sites to Watch Any Game For Free’, (2015) International Business Times.

${ }^{43}$ Jared Lynch., 'Illegal sports piracy networks undercutting TV networks', Sydney Morning Herald (online), 1 June 2015 <http://www.smh.com.au/business/illegal-sports-piracy-networks-undercutting-tv-networks-20150530-ghd65z.html> (last accessed 28 November 2016).
} 
connect with the server through a privately obtained set top box. The latter would require a connection from the privately obtained set top box to a computer with a 'PC-TV' tuner card. ${ }^{44}$ Although this has the potential to rob traditional broadcasters of their ability to monetise sports broadcast rights, traditional broadcasters like Foxtel have fought back. Their set top boxes allow content to be recorded for later viewing, but have such limited storage space that older recordings must be deleted in order to store new content. Free-to-air television channels also allow viewers to play back content online for a number of days after airing, and play repeats of broadcasted content at different times on television. ${ }^{45}$ Nevertheless, this form of live streaming is still a cause for concern. It was only as recent as early February 2017 where some users had live streamed the highly anticipated Danny Green v Anthony Mundine boxing match on Facebook through their subscription to Foxtel. At its peak, 153,00 users were watching the live stream on Facebook for free when Foxtel was charging customers nearly $\$ 60$ to watch the fight on its Main Event channel. ${ }^{46}$ This continued despite a tense request from Foxtel representatives asking them to stop live streaming during the match.

The final method of live streaming is more simplistic. It involves individuals recording sports matches with their mobile phones and streaming it live through applications such as Periscope and Meerkat. These applications access an individual's Twitter account and show a list of live videos posted by all of the individual's Twitter connections. They allow users to store the live videos for replay for 24 hours. Unsurprisingly, the issue with this live-streaming capability is copyright infringement. Users could live stream videos of sports matches directly (from being in the audience of a match) or from television to any viewers who use the application, undermining the sports broadcasting rights of traditional broadcasters. Both Periscope and Meerkat forbid users from posting videos that would constitute copyright infringements, but monitoring and enforcing this rule is difficult, especially when Periscope alone has more than 10 million users who have produced more than 200 million broadcasts. ${ }^{47}$ In one instance, Periscope was given more than 140 infringement notices to remove live videos by users who were streaming a highly publicised boxing match. ${ }^{48}$

This raises the relevant question of why individuals choose to engage in the illegal streaming of sports broadcasts. Users of these illegal sites argue that, in providing legitimate means of accessing the material, sporting codes and original broadcasters 'are holding sport fans to ransom'. ${ }^{49}$ They have claimed that the original broadcasters and sporting codes have discriminated against people based on where they live and how much they earn, arguing that games are showed at particular times on television to force people to attend stadiums. ${ }^{50}$ For example, there have been 'blackouts' in the

\footnotetext{
${ }^{44}$ Michael J. Mellis., 'Internet Piracy of Live Sports Telecasts’ (2008) 18(2) Marquette Sports Law Review $259,263$.

${ }^{45}$ Channel 7, 9, 10, Go! and ABC iView are examples of this.

${ }^{46}$ Lily Mayers and Riley Stuart, Danny Green vs Anthony Mundine live streamers will face legal action from Foxtel (5 January 2017) at <http://www.abc.net.au/news/2017-02-04/green-v-mundine-live-streamers-warned-to-brace-for-legal-action/8241276> (last accessed 5 February 2017).

${ }^{47}$ Kia Kokalitcheva, 'Here’s how much periscope has grown in its first year', Fortune (online), 28 March 2016 <http://fortune.com/2016/03/28/periscope-one-year-birthday/> (last accessed 20 December 2016).

${ }^{48}$ Queenie Wong, 'Anti-piracy battle unfolds in real time on Periscope, live-streaming apps' San Jose Mercury News (online), 20 September 2015. <http://www.mercurynews.com/business/ci_28846415/anti -piracy-battle-unfolds-real-time-periscopelive $>$ (last accessed 3 December 2016).

${ }^{49}$ Howard Swains., 'Free football streaming: how illegal sites keep outpacing broadcasters' The Guardian (online), 1 August 2015 <http://www.theguardian.com/football/2015/aug/01/faster-easier-free-illegal-football-streams> (last accessed 30 December 2016)

${ }^{50}$ Ibid.
} 
United Kingdom of live soccer broadcasts on Saturdays between 2:45 p.m. and 5:15 p.m. since the 1960s. ${ }^{51}$ It has also been highlighted that the amount of people who are viewing sporting games without attending the event is the highest it has ever been. ${ }^{52}$

A more fundamental reason behind illegal streaming is the freedom of expression, which is widely seen as underpinning human rights and democratic freedoms. The freedom of expression requires public platforms and can only be effective if information, entertainment and ideas can be freely exchanged. ${ }^{53}$ Monetising sports broadcast rights inevitably means that the cost will need to be recouped by traditional broadcasters. This is usually passed on to the viewers in the form of high subscription rates, which in effect, act as a barrier to the free flow of entertainment and knowledge. Illegal live streaming provides the opportunity for viewers who cannot afford to access legitimate services to enjoy sports matches. From an economic cost-benefit analysis, the marginal cost of sharing a live sports match online for others to view (through illegal streaming) is almost nil, thereby maximising the benefit to society. When news broke that Foxtel had turned off a user's subscription for live streaming the Danny Green v Anthony Mundine boxing match, another feed soon started up. When Foxtel tracked the other user down and successfully asked him to turn off his Facebook stream, dozens of others stepped in, streaming the match on other platforms like Youtube and Periscope. A wellrespected commentator, David Lipson (from ABC's Lateline program) immediately leapt to the live streamers' defence. As Lipson argued:

...claims that live streaming threaten the sustainability of the industry are wrong. The real threat to the viability of any industry is a company's inability to adapt to technology and keep up with the demands of its users. Consumers these days insist on instant access. If it's not easy to buy, and relatively cheap, technology allows them to go elsewhere... It's due to the fact the only legal way to watch the show is to sign a lengthy subscription with the rights holder, Foxtel. $^{54}$

On the other hand, monetised sports broadcast rights continue to exist. For example, the AFL (Australian Football league) broadcast rights deal is the richest in Australian sport history, outdoing its $\$ 1.253$ billion deal for $2012-2016 .{ }^{55}$ The revenue generated by these broadcasting rights allows sporting codes to function and pay their players. Illegal streaming impedes the ability of sporting codes to enter into such contracts. Tony Ishak, the managing director of World Media International, referred to illegal streaming as being 'like a big cancer that is going to eat up your whole organization'. Ishak further stressed that 'it seems everyone is waiting for the problem to get big enough before they act, but by then it could be too late'. ${ }^{56}$

\footnotetext{
${ }^{51}$ Alistair Cameron., Football's coming into the home - but how can broadcasters target pirates re-streaming live sports? (14 August 2015) SoccerEx <https://www.soccerex.com/news/2015/08 /football's-coming-home---how-can-broadcasters-targetpirates-re-streaming-live-sports> (last accessed 3 November 2016).

52 Ibid.

${ }^{53}$ European Commission, 'Freedom Of Expression, Media And Digital Communications’ (2012) at

$<$ https://ec.europa.eu/europeaid/sites/devco/files/study-freedom-expression-communication-key-issues-201212_en_3.pdf>(last accessed 2 February 2017).

${ }^{54}$ David Lipson, Freen v Mundine: How two blokes outsmarted Foxtel and why it should get on board (5 February 2017) at <http://www.abc.net.au/news/2017-02-05/how-two-blokes-outsmarted-foxtel/8241800> (last accessed 5 February 2017).

${ }^{55}$ Foxsports at http://www.foxsports.com.au/afl/afl-2508-billion-broadcast-rights-deal-stacks-up-well-with-other-sportsleagues-worldwide/news-story/934466dae31b486ab3124008988734fc (last accessed 27 February 2017).

${ }^{56}$ Jared Lynch., 'Illegal sports piracy networks undercutting TV networks', Sydney Morning Herald (online), 1 June 2015 <http://www.smh.com.au/business/illegal-sports-piracy-networks-undercutting-tv-networks-20150530-ghd65z.html> (last accessed 1 December 2016).
} 
Addressing illegal streaming of sporting events has been a significant burden on law enforcement bodies and copyright owners. It has been difficult to obtain evidence when taking action against illegal live streamers, partly because the matches are not stored permanently on the streamer's computer. When the end-user/viewer shuts down the computer or any other device that facilitates streaming, the files that have been temporarily stored on such a device are erased.

\section{Copyright protection for live streaming of sports broadcasts}

It is important to note that under Australian Law, copyright does not subsist in an actual sporting event. Although section 248G(1)(a) of the Copyright Act 1968 (Cth) provides that ' $[\mathrm{a}]$ person makes an unauthorised use of a performance if the person ... makes a direct or indirect recording of the performance', section 248A(2) stipulates a sporting event does not amount to a performance. This was affirmed in Australian Olympic Committee v Big Fights Inc. ${ }^{57}$ where Justice Lindgren held that a sporting event did not amount to 'dramatic work' within section 31 of the Act. His Honour found that sporting events were random in nature and did not involve preplanned choreography. ${ }^{58}$ Although there is no copyright in a sporting spectacle itself, it is recognised in Australia that copyright subsists in a broadcast of a sporting event. Section 91 of the Copyright Act provides that copyright subsists in television and sound broadcasts. The copyright can subsist even if there is no copyright in the underlying material being broadcast. For example, there is no copyright in a sporting match or spectacle, but the maker of the broadcast of that match or spectacle will have copyright in the broadcast. ${ }^{59}$

Yet the Copyright Act is limited to protecting creators' works of authorship. This includes 'literary', 'dramatic' and musical and artistic works, sound recordings and cinematographic works that are 'original' to the author. In order to meet the originality under copyright law, a work must be independently created (as opposed to copied from other works) and possess at least 'some minimal degree of creativity'. This raises the relevant question: Does broadcasting meet the criterion of originality? The creation of broadcasting requires a certain degree of creativity. For example, the choice of lens for recording events, editing, a new screen for viewing the picture and possession of original elements such as logos, graphics and music are all undoubtedly creative elements and not just merely a record of events. ${ }^{60}$ In addition, copyright only protects a work that is in a 'material form'. The meaning of 'material form' covers any visible or non-visible form of storage. Section 10 of the Act defines material form to include, in relation to a 'work' or an 'adaptation of a work', any form (regardless of whether it is visible) of storage of the work or adaptation, or a substantial part of the work or adaptation (whether or not the work or adaptation, or a substantial part of the work or adaptation can be reproduced). ${ }^{61}$ Reproduction

\footnotetext{
${ }^{57}$ [1999] FCA 1042.

58 (1999) 46 IPR 53, 67; Victoria Walk., 'No Free Kicks: Copyright in the Sporting Arena’ (2009) 28 (3) Communications Law Bulletin 22, 22.

${ }^{59}$ There are three relevant definitions in section 10 of the Act:

"Broadcast" is defined as "a communication to the public delivered by a broadcasting service within the meaning of the

Broadcasting Services Act 1992 (Cth)." “Television broadcast” means “visual images broadcast by way of television, together with any sounds broadcast for reception along with those images", "Sound broadcast” means "a broadcast otherwise than as part of a television broadcast”, see Copyright Subsistence: Subject Matter Other than Works (Part IV) at

$<$ http://wikijuris.net/ausip/copyrightsubsp4>(last accessed 16 November 2016).

${ }^{60}$ See Seagull Haiyan Song., 'New Challenges of Chinese Copyright Law in the Digital Age: A Comparative Copyright

Analysis of ISP Liability: Fair Use and Sports Telecasts' (Kluwer Law International, 2011) at 84.

${ }^{61}$ Mark Davidson (et al)., Australian Intellectual Property (Cambridge University Press, $2^{\text {nd }}$ ed, 2012) 228.
} 
occurs when a work is converted from a hard copy or analogue form into digital form. ${ }^{62}$ Thus, broadcasts of sporting events (radio or television) will be protected by copyright law as long as they are being recorded. Simultaneously, the fixation requirement in copyright law states that unless a work takes material form (such as writing or making a sound recording or video recording of it), the work does not qualify for copyright protection. ${ }^{63}$ Since the broadcasts of the sporting events are recorded onto videotape, film, or other media format at the same time that they are disseminated, the broadcasts are fixed in tangible form.

The question then becomes whether live streaming constitutes a broadcast. The case law suggests that this is not the case. For example, in Phonographic Performance Company of Australia Ltd v Commercial Radio Australia Ltd., ${ }^{64}$ the Full Federal Court found that an Internet simulcast did not amount to a broadcast. Keeping in mind that live streaming is a simulcast of content by a traditional broadcaster, the judgement effectively found that live streaming did not fall within the definition of a broadcast. Even if live streaming amounted to a 'retransmission' within section 10 of the Copyright Act, section 135ZZJA(1) specifically excludes internet retransmission from any of the obligations and requirements listed in Part VC of the Act which relates to the retransmission of free-to-air broadcasts. Arguably, the term 'broadcast' in the Copyright Act does not intend to incorporate internet transmission of content, which would include streaming.

On the other hand, section 6 of the Broadcasting Services Act 1992 (Cth) defines a 'broadcasting service' to mean 'a service that delivers television programs or radio programs to persons having equipment appropriate for receiving that service, whether the delivery uses the radiofrequency spectrum, cable, optical fibre, satellite or any other means or a combination of those means'. A ministerial determination, made in 2000 under the Broadcasting Services Act, excludes a 'service that makes available television and radio programs using the internet' from the definition of a broadcasting service'. ${ }^{65}$ According to the determination, streaming of television programmes cannot be considered as broadcasting.

In Win Corporation $v$ Nine Network Australia Pty $L t d,{ }^{66}$ the question arose whether the term 'broadcast' which has traditionally been used for television and radio programmes, can be applied to live-streaming on the internet as used in the agreement between Nine and WIN. WIN Corporation had sought an injunction restraining the Nine Network from live internet streaming its programming to areas covered by broadcasting licences held by WIN. This was on the basis of clause 2.1 of their written Program Supply Agreement (PSA), which provided that:

Nine grants WIN the exclusive licence to broadcast on and in the licence areas covered by the WIN Stations the program schedule broadcast by Nine on each of the channels known as 'Nine', 'NineHD', '9Go', '9Gem', 'Extra' and '9Life' (the 'Nine Channels'), to be picked up by WIN at Nine’s NPC.

\footnotetext{
${ }^{62}$ Ibid, Section 10 (1), Copyright Act, 1968.

${ }^{63}$ Copyright Act 1968 (Cth) section 22.

${ }^{64}$ [2013] FCAFC 11.

${ }^{65}$ Commonwealth of Australia Gazette-Determination under Paragraph (c) of the Definition of 'Broadcasting Service', (No 1 of 2000), Commonwealth of Australia Gazette No GN 38, 27.

${ }_{66}^{6}$ [2016] NSWSC 523.
} 
WIN claimed that Nine was in breach of the PSA because Nine's live internet streaming of content in licenced areas amounted to broadcasting within the PSA. Justice Hammerschlag found that this was not the case and declined to grant an injunction. His Honour argued that the correct approach was Nine's definition of broadcasting. Nine contended that in its natural and ordinary meaning, broadcasting referred to 'transmission by radio or television, and that as used in the context of the whole of the PSA ... free-to-air' ${ }^{67}$ The licence areas referred to in clause 2.1 related to the geographical limitations imposed on WIN under the Broadcasting Services Act, which only covered free-to-air. ${ }^{68}$ His Honour further argued that WIN only broadcasted free-to-air under such licences and did not deliver by internet. Furthermore, there was a contextual context as both parties knew that Nine was not in a position to give internet streaming rights to WIN based on previous discussions tendered to the Court.

Although this concerned internet streaming, this was a contractual dispute about the definition of broadcast within the PSA as the parties intended. As his Honour noted:
Bespoke definitions of 'broadcast' in various legislative enactments are not of assistance in the construction of the particular instrument under consideration here...
My conclusion that 'broadcast' means free-to-air disposes of the necessity to consider WIN's ultimate preferred construction of clause 2.1, being that broadcast means by any means, but that it can only exercise the right free-to-air. However, I consider it commercially highly unlikely that the parties would have intended to achieve such a result by the use of and through the words which they chose. ${ }^{69}$

The Court held that live internet streaming is not 'broadcasting' within the meaning of the Nine-WIN agreement.

\section{Temporary or incidental reproductions}

It is unclear under Australian copyright law whether temporary or incidental reproductions (while making available and transmitting copyright material electronically) can amount to an infringement. This uncertainty is directed towards any browsing on the Internet, which involves temporary copies of copyright material being stored in the memory of the user's computer. ${ }^{70}$ In Australian Video Retailers Association Ltd $v$ Warner Home Video Pty Ltd., ${ }^{71}$ the Federal Court of Australia held that the temporary storage of a film in the random access memory (RAM) of a DVD player (while the DVD was being played) did not constitute a 'reproduction' of the movie. ${ }^{72}$ Justice Emmett found that temporary and ephemeral copying of the film in a DVD player's RAM during the playing process was not a copy of the whole or a substantial part of the film under the Act.

\footnotetext{
${ }^{67}$ at [52].

${ }^{68}$ at [82].

${ }^{69}$ at [84] - [85].

${ }^{70}$ Gaye Middleton., ‘Copyright Beyond the Digital Frontier - Australia's Proposed Digital Agenda Reforms’ [1999] Journal of Law, Information and Science (1999) 10(1) 52.

${ }^{71}$ (2001) F.C.A 1719 (Fed Ct (Aus).

${ }^{72}$ Gaye Middleton., 'Australia: Intellectual Property-Copyright (2002) 8 (5) Comp and Telecom L. Review, quoted in Maurizio Borghi., 'Chasing Copyright Infringement in the Streaming Landscape' (2011) 42 (3) International Review of Intellectual Property and Competition Law, 1, 18
} 
On the other hand, section 21 of the Copyright Act describes the term 'reproduction' as:

a literary, dramatic or musical work shall be deemed to have been reproduced in a material form if a sound recording or cinematograph film is made of the work, and any record embodying such a recording and any copy of such a film shall be deemed to be a reproduction of the work. ${ }^{73}$

According to section 21 (1A) of the Act 'a work is taken to have been reproduced if it is converted into or from a digital or other electronic machine-readable form, and any article embodying the work in such a form is taken to be a reproduction of the work'. Moreover, section 21 (6) of the Act states that 'a sound recording or cinematograph film is taken to have been copied if it is converted into or from a digital or other electronic machine-readable form, and any article embodying the recording or film in such a form is taken to be a copy of the recording or film' ${ }^{74}$

However, there are a few exceptions for the reproductions under the Australian copyright law. For example, sections 43A and 111A of the Copyright Act provides that there is no copyright infringement if there is a temporary reproduction of a work or an audio-visual item ${ }^{75}$ as part of the technical process of making or receiving a communication. However, this is only the case if the making of the communication itself does not infringe copyright. ${ }^{76}$ The purpose behind these exemptions is to ensure that copyright owners do not unduly interfere in caching, browsing or viewing copyright-protected material online, or when incidental reproductions are made as part of a technical process. On the other hand, sections $43 \mathrm{~A}$ and $111 \mathrm{~A}$ provide that 'the exceptions do not apply in relation to the making of a temporary reproduction of a work, or an adaptation of a work, as part of the technical process of making a communication if the making of the communication is an infringement of copyright'. ${ }^{77}$ This means that sections $43 \mathrm{~A}$ and $111 \mathrm{~A}$ will not defer a person from copyright liability if the making of the communication is in itself an infringement of copyright. Essentially, sections 43A and 111A of the Act exempt reproductions, but not the copyright owner's communication right; for example, the exceptions will not apply if the temporary copy arises from a use that infringes copyright or is communicated to a user. Consequently, sections 43A and 111A do not suggest that looking at material on a computer screen or browsing will not infringe copyright. The end-user/viewer could be in breach if (s)he makes a temporary reproduction during the streaming of a copyright-protected work without the consent of the copyright owner. This, however, would depend on whether there is enough data being copied to the viewer's hard drive cache to amount to an infringement on the right of reproduction. It appears that simply reproducing a sporting event on a computer screen would not amount to a reproduction under the Copyright Act. Reproduction requires the content to be 'embedded' or fixed (the term 'embodied' is also used interchangeably) in a record.

\footnotetext{
${ }^{73}$ Copyright Act 1968 (Cth) s Section 21 (1).

${ }^{74}$ See also Jonathon Barlow., 'Copyright - who has the right to rent DVDs?' at

<http://www.findlaw.com.au/articles/580/copyright---who-has-the-right-to-rent-dvds.aspx> (last accessed 30 November 2016).

${ }^{75}$ Section 111A of the Copyright Act.

${ }^{76}$ See Gaye Middleton., 'Australia: Intellectual Property-Copyright (2002) 8 (5) Comp and Telecom L. Review, quoted in Maurizio Borghi., 'Chasing Copyright Infringement in the Streaming Landscape’ (2011) 42 (3) International Review of Intellectual Property and Competition Law, 1, 18.

${ }^{77}$ ALRC., 'Caching, indexing and other internet functions' at < http://www.alrc.gov.au/publications/issues-paper/cachingindexing-and-other-internet-functions>, see also ALRC, 'Incidental or Technical Use and Data and Text Mining' at $<$ https://www.alrc.gov.au/publications/11-incidental-or-technical-use-and-data-and-text-mining/incidental-or-technical-use> (last accessed 3 November 2016).
} 
The issue of the requirement of embodiment was canvassed by the Federal Court in Seven Network Ltd $v$ Commissioner of Taxation. ${ }^{78}$ The Seven Network was granted the exclusive right to transmit Olympic events produced by the Swiss-based International Olympic Committee ('the IOC') in return for the payment of the fee. ${ }^{79}$ The Commission of Taxation claimed that tax was payable under Article 12 of the 'Agreement between Australia and Switzerland for the Avoidance of Double Taxation with respect to Taxes on Income', which provided, inter alia, that tax could be paid on copyright licence fees. ${ }^{80}$ The Commissioner argued that copyright subsisted in the digital signal as a 'cinematograph film' for the purposes of section 10 of the Copyright Act on the basis that the sporting events were embodied in the signal. ${ }^{81}$ However, Bennett $\mathrm{J}$ held that the signals did not amount to cinematograph films as the signals were received simultaneously by the Seven Network and not embodied/embedded in any recorded form including through the receiving cables. As it was argued:

There is no embodiment of an aggregate of visual images in the ITVR Signal. There is no embodiment of any aggregate of visual images in a 'thing'. Even if it be accepted that digital embodiments of visual images can satisfy the definition of cinematograph film, the Act requires that there be an embodiment. Here, there were no images stored in the ITVR Signal at any time. There was no location where an aggregate of data, representing the visual images carried by the electrical signals from the different feeds that constitute the film, has been embodied for the purposes of the use in Seven's broadcast so that those visual images could be reproduced. ${ }^{82}$

This decision confirms that the transmission of data comprised of digital feed of images and sounds itself is not considered a subject matter of copyright law. It also validates the complicated and technical nature of copyright in live streaming.

\section{Copyright owner's exclusive right of communication to the public}

Under Australian copyright law, the right to communicate to the public is comprised of two sub-rights: (a) the right to make copyright-protected works available online and (b) the right to transmit such works electronically. The Copyright Act defines the term 'communicate' as making 'available online or transmitting (whether over a path, or a combination of paths, provided by a material substance or otherwise) a copyright work'. ${ }^{83}$

Along with its broad scope, the communication right raises many liability concerns for live streamers in Australia. One such concern involves ascertaining who would be liable if there was an infringement of this right. Section 22 (6) of the Copyright Act states that '[f]or the purposes of [the] Act, a communication other than a broadcast is taken to have been made by the person responsible for determining the content of the communication'. The question that arises here is who is 'the person

\footnotetext{
${ }^{78}$ [2014] FCA 1411.

79 [2014] FCA 1411, [1]-[2].

${ }^{80}$ [2014] FCA 1411, [4]-[6].

${ }^{81}$ [2014] FCA 1411, [15], [50].

82 [2014] FCA 1411, [120].

${ }^{83}$ Section 10 of the Copyright Act 1968 defines "communicate” in the following manner: Communicate means make available online or electronically transmit (whether over a path, or a combination of paths, provided by a material substance or otherwise) a work or other subject matter.
} 
responsible for determining the content of the communication'? In 2006, section 22(6A) was inserted into this provision to ensure that the end-user cannot be construed as this person. ${ }^{84}$ This is reflected in the Explanatory Memorandum of the Copyright Amendment Bill 2006 (Cth), which stresses that 'it was never intended that a person doing no more than merely accessing copyright material online could be considered to be exercising the communication right in relation to what was accessed'. ${ }^{85}$ Accordingly, the actual viewer of an online video cannot be considered to be the person who has communicated it.

Nonetheless, section 36 (1) of the Copyright Act states that 'the copyright in a literary, dramatic, musical or artistic work is infringed by a person who, not being the owner of the copyright, and without the license of the owner of the copyright, does in Australia, or authorises the doing in Australia of any act comprised in the copyright.' A strict reading of section 36 of the Copyright Act suggests that any act regarding online content constitutes an infringement if is carried out 'without the licence of the owner of the copyright'. Original broadcasters of sport therefore have the right to prevent others from retransmitting the content to an online audience.

Moreover, under section 87 of the Copyright Act, copyright in the actual broadcast provides the owner with the 'exclusive right' to 'make a cinematograph film of the broadcast', 'make a sound recording of the broadcast' and 're-broadcast or communicate the television or sound broadcast to the public otherwise than by broadcasting it'. In the case of sporting events, copyright in the film or broadcast generally lies with the broadcaster or the relevant sporting organisation. ${ }^{86}$ Accordingly, under section 87 of the Act, it is an infringement of copyright for a person other than the rights holder of a film or broadcast to make a copy of that film or broadcast and to 'communicate it to the public'. Further, under section 86 of the Act, copyright in a cinematograph film vests the owner with the 'exclusive right' to 'make a copy of the film', 'cause the film to be seen or heard in public' and 'communicate the film to the public'.

In the recent case of Dallas Buyers Club LLC v iiNet Ltd., ${ }^{87}$ Dallas Buyers Club (DBC) argued that sharing a film (as opposed to the downloading of the film) infringed its copyright by communicating the film to the public under section 86 of the Copyright Act. This argument was put forward in relation to the application for discovery, and although Justice Perram did not have to decide on this issue, he was 'comfortably satisfied' from 'strong circumstantial evidence that the end-user was infringing the copyright in the film'. ${ }^{88} \mathrm{DBC}$ argued that BitTorrent purportedly contravened section 86(c) of the Copyright Act by communicating the film to the public. Justice Perram contended ${ }^{89}$ that the issue was whether an end-user, having been detected a sliver of a film, may have been involved in making the film available online within the meaning of section 10 as section 10 of the Copyright Act defined 'communicate' to include 'make available online'.

\footnotetext{
${ }^{84}$ Mark Davison, Ann Monotti and Leanne Wiseman., Australian Intellectual Property Law (Cambridge University Press, $2^{\text {nd }}$ Edition, 2012) 242, 243.

${ }^{85}$ Explanatory Memorandum, Copyright Amendment Bill 2006 (Cth) 130; Mark Davison, Ann Monotti and Leanne Wiseman, Australian Intellectual Property Law (Cambridge University Press, $2^{\text {nd }}$ Edition, 2012) 242, 243.

${ }^{86}$ Submission to Senate Inquiry into the Reporting of Sports News and Digital Media' at 2.

${ }^{87}$ [2015] FCA 317

${ }^{88}$ See para [30].

${ }^{89}$ [2015] FCA 317.
} 
In this case, DBC and its parent company Voltage Pictures successfully secured orders in the Federal Court requiring several internet service providers to hand over details of accounts they suspected of infringing their copyright. Specifically, they had sought access to documents that could identify the account holders of 4,726 IP addresses which were purportedly used to share the film they had produced. This was a preliminary discovery application, but in doing so, DBC gave evidence about a file sharing mechanism called BitTorrent. ${ }^{90}$ BitTorrent was a peer-to-peer network where computers linked together to share information, files or data. Whenever a user downloaded a file via BitTorrent (like a pirated version of the movie in question), the user was simultaneously sharing a portion of that file with other users on the network. In this sense, a downloaded file from BitTorrent compiled together portions shared by other users. The sharing aspect was the basis in which DBC claimed that BitTorrent infringed on its copyright.

Although the Court concluded that DBC had a right to sue those who had been sharing the film in copyright infringement, DBC ultimately failed to obtain the details of the account holders in subsequent decisions because the Court imposed restrictions on what DBC could do with the account holders' details. Justice Perram had put a stay on the order granting preliminary discovery unless DBC took certain steps, but DBC declined and subsequently decided not to pursue the action. However, this does not negate the significance of Justice Perram’s views.

Based on this decision, it can be argued that facilitating the illegal streaming of live sports could potentially contravene a copyright holder's exclusive right to communicate to the public given that live streaming essentially involves sharing a broadcast to others. For example, an end-user who watches a live program on an illegal live streaming platform has the ability to share the same program with another peer who is interested in watching it.

Although the subject matter of National Rugby League Investments Pty Ltd v Singtel Optus Pty $L t d^{91}$ was linked to a streaming service, the analysis of the case was firmly based on time-shifting exception and reproduction because the given service was clearly designed to cater the end-users to record the matches at a preferred time. In this case, Optus had launched a cloud-based TV recording service, TV Now. This enabled customers to record free-to-air TV programs. These recordings were stored on Optus' cloud storage platform and customers could stream the recorded programs to their compatible devices. The Australian Football League and the National Rugby League (the copyright owners of football broadcasts), along with Telstra (the exclusive licensee) claimed that Optus infringed their copyright by providing this recording service. The provision in question was section 111 of the Copyright Act and whether the time-shifting exception could be applied. However, the significance of this case for the purposes of live streaming comes from the Federal Court and the Full Federal Court's analysis of a 'user'. There was a marked difference between the trial court and on appeal on who the relevant 'user' should be in determining whether a user breached copyright laws.

At first instance, the trial judge had found that the relevant 'user' for copyright purposes was the subscriber of the TV recording service, not Optus. Justice Rares found that although Optus provided the technology, it was ultimately the person who

\footnotetext{
${ }^{90}$ At 25-32.

${ }^{91}$ (2012) 201 FCR 147
} 
chose to record the program who constituted the user. ${ }^{92}$ However, on appeal, the Full Federal Court found that it was either Optus, or Optus and the subscriber acting together, who constituted the relevant user. They felt that it was unnecessary to make a definitive conclusion, but their preferred view was to categorise Optus and the subscriber acting together. The Full Court found that although the subscriber selected the programme to be recorded, it was Optus which gave effect to it. Without Optus' involvement, nothing would have been copied. It further argued that:

We consider that Optus' role in the making of a copy - ie in capturing the broadcast and then in embodying its images and sounds in the hard disk - is so pervasive that, even though entirely automated, it cannot be disregarded when the 'person' who does the act of copying is to be identified. The system performs the very functions for which it was created by Optus. ${ }^{93}$

This decision suggests that when it comes to ascertaining who should be responsible for the illegal streaming of live sports, the media content provider, or the media content provider acting together with the viewer of the illegal streaming, would be the relevant parties that are breaching copyright laws.

In Roadshow Films $v$ iiNet Ltd., ${ }^{94}$ thirty-four film companies had commenced proceedings in the Federal Court against iiNet on the basis that it had 'authorised' the copyright infringements of its users. The film companies, through the Australian Federation Against Copyright Theft (AFACT), had found that users were infringing on their copyright by downloading and sharing content on BitTorrent. AFACT sent notices to iiNet about these breaches and demanded that iiNet prevent further infringement by warning, suspending or terminating the internet service of those users. iiNet declined to take any action. The copyright owners subsequently launched legal action against iiNet on the basis that it had authorised its users' copyright infringement by breaching section 101 of the Copyright Act. Section 101 provided that copyright could be infringed upon by authorising another's copyright infringement. This required a consideration of three factual matters:

(i) the extent (if any) of the person's power to prevent the copyright infringement;

(ii) the nature of any relationship between the person and the copyright infringer; and

(iii) whether the person took any other reasonable steps to prevent or avoid the doing of the copyright infringement, including complying with any relevant industry codes of practice. ${ }^{95}$

Roadshow/AFACT argued that iiNet had authorised the copyright infringement through its internet service; its ability to control the use of that service and to give warnings, suspension and termination; and its inaction after notices were sent to iiNet. The High Court, however, disagreed and argued that an indifference to a user's

\footnotetext{
${ }^{92}$ He was particularly drawn to the High Court's earlier decision in University of New South Wales $v$ Moorhouse where he argued: ... Critically, for present purposes, Gibbs J said that it was 'impossible to hold' that the University did the act of photocopying when the student copied the part of a book in its library (133 CLR at 11). 'In my opinion, there is a reasonable analogy between the University's provision of the photocopier and Optus' provision of the TV Now service. Each of them provided a means for a third person - a student or a user - to make a copy or a film. But, as Gibbs J reasoned, it was impossible to say that the University did the act of photocopying by providing the photocopier, just as, in my opinion, it is impossible to say that Optus makes any of the films in the four formats that are created when a user clicks "record" and its data centre carries out that instruction'.

${ }^{93}$ (2012) 201FCR 147 at [58].

94 [2012] HCA 16.

95 101(1A) of the Copyright Act 1968.
} 
copyright infringement was not an authorisation. Furthermore, even if iiNet had exercised its power to terminate internet accounts, users could simply go to another service provider. As noted by French CJ, Crennan J and Kiefel J:

The extent of iiNet's power was limited to an indirect power to prevent a customer's primary infringement of the appellants' films by terminating the contractual relationship between them. The information contained in the AFACT notices, as and when they were served, did not provide iiNet with a reasonable basis for sending warning notices to individual customers containing threats to suspend or terminate those customers' accounts. For these reasons, iiNet's inactivity after receipt of the AFACT notices did not give rise to an inference of authorisation (by 'countenancing' or otherwise) of any act of primary infringement by its customers. ${ }^{96}$

On this basis, a media content provider that simply facilitates the illegal streaming of live sports would not appear to be in breach of section 101 of the Act since it is not making any positive action that demonstrates an authorisation. However, the approach in iiNet appears to have been circumvented by the recent decision of Dallas Buyers Club LLC.

\section{Peer to Peer live streaming and copyright infringement}

As discussed earlier in the paper, peer-to-peer (P2P) systems provide a scalable way to stream content to multiple receivers over the Internet. ${ }^{97}$ This can be completed in two ways; firstly the end-user can capture the event discretely and distribute through the Internet. Secondly, the end-user can access to a live streaming event through the Internet and re-distribute it to peers or to public using another platform such as torrents. When online content available on the Internet (such as sporting events) is re-distributed by an end-user using peer-to peer streaming, they are making such content available for the general public. Therefore, in an event where an end-user is engaged in sharing or distributing online content by using illegal streaming methods that are stated above, the end-user is undoubtedly considered as an infringer of copyright.

Section 13 of the Copyright Act provides that only the owner of a copyright has the right to authorise another person to exercise their legal rights under the legislation. The High Court in University of New South Wales $v$ Moorhouse ${ }^{98}$ established that authorisation includes to 'sanction, approve, [or] countenance' an infringement of copyright by other persons. In doing so, the court held that 'passive involvement' can still amount to an authorisation if it involved the ability to prevent breaches from occurring by others. ${ }^{99}$ Section 13 of the Act should be read alongside section 39B, which provides that simply providing a method of communication does not amount to an infringement of copyright. ${ }^{100}$ In Moorhouse, the court held that a university, by

\footnotetext{
96 at 78.

${ }^{97}$ Sudipta Sengupta, 'Peer-to-Peer Streaming Capacity' (2011) 57 (8) IEEE Transactions on Information Theory $5072-5087$.

98 (1975) 133 CLR 1, 12, 20-1.

99 Bryan Mercurio., 'Internet Service Provider Liability for Copyright Infringements of Subscribers: A Comparison of the American and Australian Efforts to Combat the Uncertainty' (2002) 9(4) Murdoch University Electronic Journal of Law 51; University of New South Wales v Moorhouse (1975) 133 CLR 1, 12, 20-1.

${ }^{100}$ The Online Copyright Infringement Discussion Paper (September 2014) Universities Australia

<https://www.universitiesaustralia.edu.au/ArticleDocuments/695/Submission\%20in\%20response\%20to\%20the\%20Online\%20

Copyright\%20Infringement\%20Discussion\%20Paper.pdf.aspx> (last accessed 5 October 2016).
} 
providing coin operated photocopiers and open book shelves that could be used for infringing copyright, had authorised infringement because it did not take 'reasonable steps' to prevent this from occurring, such as displaying a warning sign next to the photocopier. $^{101}$

In addition, 'Australian copyright law deems that infringement of the exclusive rights of a copyrighted work can occur in one of two ways: either directly, through the express actions of the infringer; or indirectly, through the act of authorising another party (the direct infringer) to commit the infringing act'. ${ }^{102}$ In particular, section 36 (1) of the Copyright Act states that 'the copyright in a literary, dramatic, musical or artistic work is infringed by a person who, not being the owner of the copyright, and without the license of the owner of the copyright, does in Australia, or authorises the doing in Australia of any act comprised in the copyright.' Similarly, section 101 (1) provides that, 'copyright subsisting (in subject-matter other than works) is infringed by a person who, not being the owner of the copyright, and without the license of the owner of the copyright, does in Australia, or authorises the doing in Australia of any act comprised in the copyright.'

According to sections 36 (1) and 101 (1) of the Copyright Act, the copyright owners can take an action against a person who authorise the infringement. For example, in the Federal Court's earlier decision of Universal Music Australia Pty Ltd. v Sharman License Holdings Ltd. (the 'Kazaa case') ${ }^{103}$ Justice Wilcox found that the operators of the Kazaa peer-to-peer file sharing system were liable for the copyright infringements of their subscribers, who used the system to share copyright protected music files without authorisation of the copyright holder. Unlike iiNet, the Kazaa operators were aware of the widespread infringement of copyright and actively encouraged and assisted infringement. They had a financial interest in maximising copyright-infringing file sharing since their revenue came from advertising on the Kazaa system.

It must be noted, however, that many of these peer-to-peer file sharing systems are not located in Australia (even though they can be accessed in Australia). To address this issue, amendments to the Copyright Act were made to include online access disabling provisions, which came into effect on 27 June 2015 under the Copyright Amendment (Online Infringement) Act 2015 (Cth). Consequently, carriage service providers (CSP) who provide internet access to customers (such as Telstra and Optus) may also be subject to legal action for enabling access to these peer-to-peer streaming services, even though these CSP/internet providers have not committed or authorised any copyright infringement themselves. Under section 115A of the Copyright Act, the Federal Court has the power to grant an injunction to require CSPs to take reasonable steps to disable access to an online location if:

(a) a carriage service provider provides access to an online location outside Australia;

(b) the online location infringes, or facilitates an infringement of, the copyright; and

\footnotetext{
101 (1975) 133 CLR 1, 13-14.

${ }^{102}$ Sam Ricketson., J.C \& Ginsburg, 'Inducers and Authorisers: A Comparison of the US Supreme Court’s Grokster Decision and the Australian Federal Court’s KaZaa Ruling’ (2006) Columbia Law School - Columbia Public Law \& Legal Theory Working Papers at <http://lsr.nellco.org/cgi/viewcontent.cgi?article=1022\&context=columbia/pllt $>$ (last accessed 3 October 2016). ${ }^{103}[2005]$ FCA 1242.
} 
(c) the primary purpose of the online location is to infringe, or to facilitate the infringement of, copyright (whether or not in Australia). ${ }^{104}$

Importantly, section 115A provides that the parties to the action are:

(a) the owner of the copyright; and

(b) the carriage service providers; and

(c) the person who operates the online location if, but only if, that person makes and application to be joined as a party to the proceedings. ${ }^{105}$

This means that a sports broadcaster, as the owner of the copyright, can force CSP/internet providers to disable access specific online locations such as peer-topeer systems that provide livestreaming content, even if the CSP/internet providers have not committed or authorised any copyright infringement themselves. However, there is a stumbling block under section 115A(9) which provides that a CSP is not liable for any costs in relation to the proceedings unless the provider enters an appearance and takes part in the proceedings. This means that if a sports broadcaster goes ahead with the injunction and is successful, the sports broadcaster would need to bear the costs of the CSP/internet providers to block any access to the infringing websites. Although the rationale for this is so that those who benefit from the legal remedy should have the economic responsibility, it seems counterintuitive since this remedy will only be available to copyright owners who can afford the remedy.

Most recently in December 2016, the Federal Court of Australia applied these new website blocking laws in Roadshow Films Pty Ltd $v$ Telstra. ${ }^{106}$ In that case, Roadshow films successfully brought proceedings against Telstra, Optus, M2 and TPG to disable access to various online locations such as The Pirate Bay, Torrentz, Solarmovie and TorrentHound that infringed copyright. The decision also enforced section 115A(9) and required Roadshow films to bear the costs of blocking the access to the infringing websites as required. Interestingly, the judgement noted that there could still be an injunction if the website did not infringe copyright at the time the injunction was being made or if it was temporarily inactive during the proceeding. ${ }^{107}$ This is a positive move for sports broadcasters who wish to seek an injunction as all they would need to establish is a past instance of copyright infringement.

\section{Fair dealing exception}

There are fair dealing exception in Australia, which provide that the use of copyright material does not infringe copyright if it is 'fair', and that when considering whether the use is fair, certain principles or 'fairness factors' must be considered. ${ }^{108}$ Ordinarily, acts will not constitute copyright infringement if they are for the purpose of research or study, ${ }^{109}$ criticism or review, ${ }^{110}$ parody or satire, or reporting news. ${ }^{111}$ Additions were made in 2006 to recognise contemporary expectations of what should constitute legal copying. This included the 'time-shifting' exception in

\footnotetext{
${ }^{104}$ Copyright Act 1968 (Cth) s 115A(1)-(2).

105 Ibid s 115A(3).

106 (2016) FCA 1503.

107 Ibid [95].

${ }^{108}$ ALRC, The Case for Fair Use at <https://www.alrc.gov.au/publications/4-case-fair-use/what-fair-use> .

${ }^{109}$ Copyright Act 1968 (Cth) s 40.

${ }^{110}$ Ibid s 41.

${ }^{111}$ Ibid s 41A.
} 
section 111 of the Copyright Act. Section 111 applies if a person makes a cinematographic film or sound recording of a broadcast solely for private and domestic use by watching or listening to the material broadcast at a time more convenient than the time when the broadcast is made. Section 111 (2) states that the making of the film or recording does not infringe copyright in the broadcast or in any work or other subject matter included in the broadcast. Even though the making of the film or recording does not infringe that copyright, the copyright may be infringed if a copy of the film or recording is made. Thus, recording a broadcast may still infringe the copyright in any work, film or sound recording that is included in the broadcast and may infringe performer's rights if it is a live broadcast of a performance.

There are no exceptions that specifically encompass live streaming of sports broadcasting under the Copyright Act. Although section 111 of the Act provides an exception to copyright when a recording is made for 'private or domestic' use in other words, non-commercial use, live streaming of sports broadcasts is not likely to fall under this exception as the provision also requires that the recording be kept purely for viewing 'at a time more convenient than the time when the broadcast is made'. As live streaming involves almost instantaneous access to the content by the ultimate recipient, this practice would fall short of this requirement, meaning that any reliance on this provision by a person involved in live streaming, is likely to be challenged in the courts. ${ }^{112113}$

Although section 111 would not appear to have any direct relevance to the live streaming of sports broadcasts, the provision is significant because it has demonstrated the Court's reluctance to embrace digital innovation when it was litigated in National Rugby League Investments Pty Ltd v Singtel Optus Pty Ltd. ${ }^{114}$ In that case, Optus had launched a cloud-based TV recording service, TV Now, which enabled customers to record free-to-air TV programs. These recordings were stored on Optus' cloud storage platform and customers could stream the recorded programs to their compatible devices. ${ }^{115}$ The Australian Football League and the National Rugby League (the copyright owners of football broadcasts), along with Telstra (the exclusive licensee) claimed that Optus infringed their copyright by providing this recording service. Unlike the decision at first instance, the Full Federal Court unanimously found that Optus had infringed copyright in the broadcasts because they could not rely on section 111 as a defence. The Full Court noted that there was nothing in section 111 that suggested it was intended to cover commercial copying on behalf of individuals. ${ }^{116}$ To justify this reasoning, they explained that they could not use public policy as a tool of construction here:

We are conscious that the construction which we are satisfied the language of s 111 requires is one that is capable of excluding, and does in fact in this instance exclude, a later technological development in copying. However, no principle of technological neutrality can overcome what is the clear and limited legislative purpose of s 111. It is not for this Court to re-draft this

\footnotetext{
112 Ibid s 42.

${ }^{113}$ Adam Turner., 'Cricket caught in online blackout as Nine kicks of live streaming', Sydney Morning Herald (online) 29 January 2016 <http://www.smh.com.au/digital-life/computers/gadgets-on-the-go/cricket-caught-in-online-blackout-as-ninekicks-off-live-streaming-20160129-gmgtd2.html> (last accessed 18 November 2016).

114 (2012) 201 FCR 147.

115 Ibid.

${ }^{116}$ Ibid.
} 
provision to secure an assumed legislative desire for such neutrality. ${ }^{117}$

Their Honours openly acknowledged that this interpretation would not benefit future technological developments with respect to copyright infringement, and they were correct. The decision triggered the immediate abandonment of the Optus TV Now technology, which at the time was hailed as highly innovative and promising. This is a clear illustration of Australia's inability to find a coherent view of what copyright should protect and has significant implications on the future development and advancement of technologies like streaming.

\section{Where to from here? The case for reform}

The application of copyright law to streaming is considered to be in a grey area because streaming does not allow the user to copy the file or store the online content on to the computer or any other devices that facilitates streaming. It merely creates a temporary copy that cannot be permanently copied. Consequently, users can legitimately argue that merely watching a non-downloaded stream is not in contravention of the Copyright Act. ${ }^{118}$ The Australian Copyright Council noted that:

When you watch video[s] on line, material in the footage and on the soundtrack is temporarily reproduced into ... your computer's cache memory.

... However, this does not mean that you necessarily infringe copyright if you watch infringing material online. This is because, at least for material such as film and sound, you would only yourself infringe if you reproduced a 'substantial part' on an infringing copy into your temporary cache. While it's not entirely clear, there are arguments that the small amounts of film footage or sound recording held at any one time in your cache while merely watching something online may not be a 'substantial part'. ${ }^{119}$

In addition, an infringement of copyright occurs as long as a substantial portion of a work or subject matter has been reproduced or other copyright use is made of it. ${ }^{120}$ It is difficult to define with precision whether something is substantially reproduced because no definition is provided under the Act; however, the courts have recognised that this needs to be determined in light of the entire factual circumstances. ${ }^{121}$ In doing so, they have enunciated that consideration needs to be given not only to the 'quantity' of what is reproduced but also to the 'quality'. ${ }^{122}$ Thus, it is unlikely that sports organisations will have very strong claims of copyright infringement against individuals who upload illegal live streams. ${ }^{123}$ Simultaneously, the Australian Copyright Council has also made it clear that:

[C]opyright owners [however] ... are concerned about people who are uploading and downloading copies without permission, rather than people just

\footnotetext{
${ }^{117}$ Ibid [96].

${ }^{118}$ Understanding Live Streaming Content (2016) at < http://androidkingz.info/2016/06/> (last accessed 2 October 2016).

${ }^{119}$ YouTube \& Copyright (December 2014) Australian Copyright Council

<http://www.copyright.org.au/acc_prod/ACC/Information_Sheets/YouTube__Copyright.aspx> 7(last accessed 26 October 2016).

${ }^{120}$ Copyright Act 1968 (Cth) ss 36(1), 101(1).

${ }^{121}$ SW Hart v Edwards Hot Water Systems (1985) 159 CLR 466 at 482 (per Wilson J).

${ }^{122}$ IceTV Pty Ltd v Nine Network Australia Pty Ltd (2009) 254 ALR 386 at 394 per French CJ, Crennan and Kiefel JJ.

${ }^{123}$ Adam Ainslie., 'The Burden of Protecting Live Sports Telecasts: The Real Time Problem of Live Streaming and AppBased

Technology; (2015) at <http://ssrn.com/abstract=2729641> (last accessed 17 November 2016).
} 
watching the material. ${ }^{124}$

It is apparent that the Courts are limited in resolving all of these uncertainties with the Copyright Act in its current form. The High Court noted in Australian Education Union $v$ Department of Education and Children's Services ${ }^{125}$ that it could not embrace:

... a judicially constructed policy at the expense of the requisite consideration of the statutory text and its relatively clear purpose. In construing a statute it is not for a court to construct its own idea of a desirable policy, impute it to the legislature, and then characterise it as a statutory purpose. ${ }^{126}$

The problem in Australia is that the justification used by the Courts to determine whether live streaming can infringe copyright is based on legislation that did not contemplate technological advances beyond traditional broadcasting. In our view, the solution lies with legislative change to reflect these technological advances. However, any reform would require balancing the competing interests of the public (who have an increasing desire to view digital materials, the owners of the material (in terms of legal rights) and the need to foreshadow future technological advancements. With the Green v Mundine live streaming saga bringing copyright issues to the forefront (Foxtel has confirmed that it will take legal action against the live streamers ${ }^{127}$ ), reform is increasingly necessary.

\section{Conclusion}

This article began with the recognition that the rapid evolution of digital communication, including streaming, has provided significant utilitarian benefits to the community. By examining the history of sports broadcasting, the types of technology associated with streaming and the current copyright protection framework, it becomes apparent that Australia is struggling to find a clear and coherent view of what copyright should protect (and inevitably, how it should do so). Without reform, the legal uncertainty between live sports broadcasting rights and unauthorised retransmissions will remain unresolved for many years to come. As reflected in the case law, the current copyright framework appears to hamper digital innovations like streaming when it should be promoting them. Indeed, the justification used by the Courts to determine whether live streaming can infringe copyright is based on legislation that did not contemplate technological advances beyond traditional broadcasting. The incoherence underlying the Copyright Act can no longer be ignored if Australia is to embrace digital innovations (like streaming) which are becoming more prevalent in an increasingly globalised world.

\footnotetext{
${ }^{124}$ YouTube \& Copyright (December 2014) Australian Copyright Council

<http://www.copyright.org.au/acc_prod/ACC/Information_Sheets/YouTube__Copyright.aspx> 8(last accessed 17 November 2016).

${ }^{125}(2012)$ CLR 1.

126 at [28].

${ }^{127}$ Lily Mayers and Riley Stuart, Danny Green vs Anthony Mundine live streamers will face legal action from Foxtel (5 January 2017) at <http://www.abc.net.au/news/2017-02-04/green-v-mundine-live-streamers-warned-to-brace-for-legalaction/8241276> (last accessed 5 February 2017).
} 